\title{
Weed interference in the initial growth of meristem-grown sugarcane plantlets
}

\author{
Ricardo J. de Paula ${ }^{1}$, Clara D. Esposti ${ }^{1}$, Carlos R. de Toffoli ${ }^{1}$ \& Phelippe S. H. Ferreira ${ }^{1}$ \\ ${ }^{1}$ Universidade Estadual Paulista "Júlio de Mesquita Filho"/Departamento de Biologia Aplicada à Agropecuária. Jaboticabal, SP. E-mail: ricardo.jpaula@gmail.com \\ - ORCID: 0000-0001-6078-6517; claradegli@hotmail.com (Corresponding author) - ORCID: 0000-0001-7769-5099; carlos@herbae.com.br - ORCID: 0000-0002- \\ 1279-8887; phelippesantanna@gmail.com - ORCID: 0000-0001-8356-1900
}

\begin{abstract}
Key words: one-eye set weed competition weed interference Brachiaria decumbens Panicum maximum

A B S T R A C T

The use of new systems of sugarcane planting such as Plene ${ }^{\mathrm{TM}}$, Plene Evolve ${ }^{\mathrm{TM}}$, Plene $\mathrm{PB}^{\mathrm{TM}}$ and AgMusa ${ }^{\mathrm{TM}}$ requires specific studies on the initial interference of weed in the sugarcane crop. The objective of this study was to evaluate initial weed interference in meristem-grown sugarcane plantlets (Plene Evolve ${ }^{\mathrm{TM}}$ ). The weed species used were Brachiaria decumbens and Panicum maximum, at four different densities (1, 2, 3 and 4 weed plants pot $\left.{ }^{-1}\right)$, plus a control treatment free from weed interference. The statistical design was completely randomized with four replicates per treatment, with an individual study for each weed species. The evaluations performed were: plant height at 45,60 and 90 days after emergence (DAE), number of sugarcane tillers at 30,60 and 90 DAE and dry matter of both sugarcane and weed plants at 90 DAE. B. decumbens and P. maximum caused reductions in the initial growth and development of sugarcane. P. maximum was more aggressive to meristem-grown sugarcane plants, during their early development, than B. decumbens.
\end{abstract}

\section{Palavras-chave:}

mudas pré-brotadas mato competição de erva daninha mato interferência de erva daninha Brachiaria decumbens Panicum maximum

\section{Interferência de plantas daninhas no crescimento inicial de mudas meristemáticas de cana-de-açúcar}

\section{R E S U M O}

A utilização de novos sistemas de plantio de cana-de-açúcar como Plene ${ }^{\mathrm{TM}}$, Plene Evolve ${ }^{\mathrm{TM}}$, Plene $\mathrm{PB}^{\mathrm{TM}}$ e AgMusa ${ }^{\mathrm{TM}}$ demandam estudos específicos sobre a interferência inicial de plantas daninhas na cultura da cana-de-açúcar. Objetivou-se neste estudo avaliar a competição inicial exercida por plantas daninhas em mudas meristemáticas de cana-de-açúcar (Plene Evolve $^{\mathrm{TM}}$ ) em condições de vasos. Utilizaram-se as plantas daninhas capim-braquiária (Brachiaria decumbens) e capim-colonião (Panicum maximum) em quatro densidades (1, 2, 3 e 4 plantas daninhas vaso ${ }^{-1}$ ), além de um tratamento ausente de convivência. O delineamento estatístico utilizado para cada espécie de planta daninha foi o inteiramente casualizado com quatro repetições por tratamento. Foram realizadas as avaliações de altura de plantas aos 45, 60 e 90 dias após a emergência (DAE), contagem do número de perfilhos das plantas de cana-de-açúcar aos 30, 60 e 90 DAE e a massa seca das plantas de cana-de-açúcar e plantas daninhas aos 90 DAE. As espécies $B$. decumbens e $P$. maximum causaram decréscimos no crescimento inicial das plantas de cana-de-açúcar. Plantas de $P$. maximum mostraram-se mais agressivas às plantas de cana-de-açúcar no seu desenvolvimento inicial provenientes de mudas meristemáticas do que $B$. decumbens. 


\section{INTRODUCTION}

Planting is the most critical stage for a successful sugarcane field because this operation can directly interfere with its longevity, yield and economic return (Barros \& Milan, 2010). It is the practice that most involves knowledge on soil-plantatmosphere relations (Beuclair \& Scarpari, 2006), besides having direct influence on the reduction of production costs (Silva Júnior et al., 2010).

Since 2013, companies of the sugarcane sector have worked with technologies of planting one-eye (single-bud) sets, which particularly include Plene Evolve ${ }^{\bowtie}$. In Plene Evolve ${ }^{\bowtie}$, sugarcane is multiplied in laboratory through micropropagation. The meristems are removed from plantlets produced in nurseries, thermally treated and subjected to a strict phytosanitary control and serological tests to diagnose the main diseases.

Among the main problems of a sugarcane field, weed interference stands out because the reduction in crop yield may reach 85\% (Victoria Filho \& Christoffoleti, 2004). Grass species of the genera Brachiaria and Panicum deserve attention because they are characterized as aggressive, with high capacity of adaptation to low-fertility soils and phenotypical plasticity for adaptation (Lorenzi, 2008; Santos et al., 2013; Fontes et al., 2014).

With new modalities of sugarcane planting, new studies on weed interference in the crop become necessary, since one-eye sets have the advantage of exhibiting faster initial development compared with the planting of cuttings.

Based on the above, the objective of the study was to evaluate the interference of two weed species of the Poaceae family (Brachiaria decumbens and Panicum maximum) in the initial growth of sugarcane in the one-eye set planting system.

\section{Material ANd Methods}

The experiment was set up and conducted at the FCAV/ UNESP, Jaboticabal, SP, Brazil, in an area belonging to the Weeds Laboratory (LAPDA), and began on February 27, 2014, by filling the pots, planting one-eye sets of the variety RB96 6928 , and sowing the weeds. A point in the experimental area was georeferenced, with coordinates $21^{\circ} 14^{\prime} 46.9^{\prime \prime} \mathrm{S}, 48^{\circ}$ $18^{\prime} 07.4$ " W and $600 \mathrm{~m}$ of altitude. According to Köppen's classification, the climate of the region is Cwa, i.e., tropical with rains in the summer and dry winter (Alvares et al., 2013).

Cylindrical concrete pots, with $0.52 \mathrm{~m}$ diameter and $0.60 \mathrm{~m}$ height, were filled with $118 \mathrm{~L}$ of a Red Latosol collected from the surface $(0-30 \mathrm{~cm})$ of an area of the Research and Extension Farm (FEPE) of the FCAV/UNESP, Jaboticabal, SP. Fertility and texture were determined by chemical and physical analyses of a composite sample, which showed the following results
(Raij et al., 2001): $\mathrm{pH}$ in $\mathrm{CaCl}_{2}=6.1 ; \mathrm{P}\left(\right.$ resin) $=22 \mathrm{mg} \mathrm{dm}^{-3}$; $\mathrm{K}=1.2 \mathrm{mmol} \mathrm{dm}_{\mathrm{c}} \mathrm{dm}^{-3} \mathrm{Ca}=20 \mathrm{mmol} \mathrm{dm}_{c}^{-3} ; \mathrm{Mg}=11 \mathrm{mmol} \mathrm{dm}^{-3}$; $\mathrm{H}+\mathrm{Al}=16 \mathrm{mmol}_{\mathrm{c}} \mathrm{dm}^{-3} ; \mathrm{CEC}=47.7 \mathrm{mmol} \mathrm{dm}_{\mathrm{c}} \mathrm{dm}^{-3} \mathrm{~V} \%=68$; Organic matter $=13 \mathrm{~g} \mathrm{dm}^{-3} ;$ Clay $=628 \mathrm{~g} \mathrm{~kg}^{-1} ;$ Silt $=186 \mathrm{~g} \mathrm{~kg}^{-1}$ and Total sand $=186 \mathrm{~g} \mathrm{~kg}^{-1}$, and very clayey textural class.

Treatments consisted of two weed species, Brachiaria decumbens and Panicum maximum, coexisting with the sugarcane plantlets at four densities of infestation: 1, 2, 3 and 4 weed plants per pot, which correspond to the densities of 3.8 , 7.7, 11.5 and 15.4 plants $\mathrm{m}^{-2}$. Each weed species was considered as a separate study of weed interference. There was a control treatment without the presence of weeds.

Sugarcane plantlets were transplanted to the center of the pots (one plantlet per pot) and weeds were sown at a $0.15 \mathrm{~m}$ radius from the center of the pot with the aid of a template. Weed plants began to emerge on March 3, 2014, four days after sowing and, as they emerged, thinning was performed to ensure the exact density of each treatment. The pots were frequently watered to maintain adequate moisture for the development of sugarcane and weeds.

The following parameters were evaluated: number of tillers at 30,60 and 90 days after emergence of weeds (DAE), central stalk height at 45, 60 and 90 DAE (1.0-m ruler, height was considered as the distance from soil surface to the last fully exposed ligule), and shoot dry matter of sugarcane and weed plants. At $90 \mathrm{DAE}$, sugarcane plantlets and weed plants were cut close to soil surface and placed in a forced-air oven at temperature of $60^{\circ} \mathrm{C}$ to dry, until constant weight.

The obtained results were subjected to analysis of variance by $\mathrm{F}$ test, in a $5 \times 2$ factorial scheme ( 5 densities and 2 weed species), and treatment means were compared by Tukey test at 0.05 probability level. When there was significant statistical difference between treatments, polynomial regression analysis was carried out.

\section{Results AND Discussion}

According to the analysis of variance (Table 1), the two weed species only differed with respect to dry matter accumulation at 90 DAE $(p<0.05)$. Weed density significantly interfered with all evaluations performed, except for sugarcane height. The interaction between density and weed was not significant in any evaluation.

Regarding the number of sugarcane tillers (Table 2), it was observed that already in the first evaluation the treatments with $B$. decumbens showed lower numerical values than the control without coexistence, but did not differ statistically $(\mathrm{p}<0.05)$.

At 60 DAE, only the treatments with 1 and 4 plants pot ${ }^{-1}$ of B. decumbens differed from the control. In this evaluation, the

Table 1. Summary of factorial analysis of variance for the densities and species of weeds analyzed

\begin{tabular}{|c|c|c|c|c|c|c|c|c|}
\hline \multirow{3}{*}{$\begin{array}{c}\text { Source } \\
\text { of variation }\end{array}$} & \multicolumn{2}{|c|}{ Tillering } & \multicolumn{2}{|c|}{ Height } & \multicolumn{2}{|c|}{ Cane DM } & \multicolumn{2}{|c|}{ Weed DM } \\
\hline & \multicolumn{8}{|c|}{ (90 DAE) } \\
\hline & MS & $\mathbf{F}$ & MS & $\mathbf{F}$ & MS & $F$ & MS & $\mathbf{F}$ \\
\hline Density (D) & 38.78 & $8.62^{\star \star}$ & 2.21 & $0.09^{n s}$ & 1528.63 & $24.87^{\star \star}$ & 430.44 & $13.18^{\star \star}$ \\
\hline Weed species (W) & 0.90 & $0.20^{\text {ns }}$ & 0.99 & $0.33^{\text {ns }}$ & 1.59 & $0.03^{\text {ns }}$ & 867.23 & $26.56^{* *}$ \\
\hline$D * W$ & 2.22 & $0.49^{\text {ns }}$ & 0.49 & $0.74^{\mathrm{ns}}$ & 20.49 & $0.33^{\text {ns }}$ & 85.43 & $2.61^{\mathrm{ns}}$ \\
\hline
\end{tabular}

D - Density of weeds; W - Weed species; DM - Dry matter; MS - Mean square; *Significant at 0.05 probability level; **Significant at 0.01 probability level; ns - Not significant 
Table 2. Number of tillers, stalk height, dry matter of sugarcane and dry matter of Brachiaria decumbens obtained at different densities and different periods of evaluation for sugarcane

\begin{tabular}{|c|c|c|c|c|}
\hline \multirow{2}{*}{ Treatments } & \multirow{2}{*}{$\begin{array}{c}\text { Density }{ }^{1} \\
\text { (plants } \mathrm{m}^{-2} \text { ) }\end{array}$} & \multicolumn{3}{|c|}{ Number of tillers } \\
\hline & & 30 DAE & 60 DAE & $90 \mathrm{DAE}$ \\
\hline 1. One-eye set (OES) & - & $9.3 \mathrm{a}$ & $14.0 \mathrm{a}$ & $12.8 \mathrm{a}$ \\
\hline 2. $\mathrm{OES}+$ B. decumbens & $1(3.8)$ & $6.3 \mathrm{a}$ & $7.8 \mathrm{~b}$ & $8.3 a b$ \\
\hline 3. $\mathrm{OES}+$ B. decumbens & $2(7.7)$ & $7.5 \mathrm{a}$ & $9.3 \mathrm{ab}$ & $8.0 \mathrm{ab}$ \\
\hline 4. $\mathrm{OES}+$ B. decumbens & $3(11.5)$ & $8.5 \mathrm{a}$ & $10.3 a b$ & $8.8 \mathrm{ab}$ \\
\hline 5. OES + B. decumbens & $4(15.4)$ & $5.8 \mathrm{a}$ & $7.3 \mathrm{~b}$ & $7.8 \mathrm{~b}$ \\
\hline F Treatment & & $2.59^{\mathrm{ns}}$ & 5.20 ** & $3.53^{*}$ \\
\hline CV (\%) & & 24.6 & 24.3 & 24.2 \\
\hline \multirow[t]{2}{*}{ LSD } & & 4 & 5.14 & 4.82 \\
\hline & & \multicolumn{3}{|c|}{ Stalk height (cm) } \\
\hline 1. One-eye set (OES) & - & $26.3 \mathrm{a}$ & $27.3 \mathrm{a}$ & $28.5 \mathrm{a}$ \\
\hline 2. $\mathrm{OES}+$ B. decumbens & $1(3.8)$ & $23.3 \mathrm{a}$ & $25.3 \mathrm{a}$ & $25.8 \mathrm{a}$ \\
\hline 3. $\mathrm{OES}+$ B. decumbens & $2(7.7)$ & $24.5 \mathrm{a}$ & $25.0 \mathrm{a}$ & $24.8 \mathrm{a}$ \\
\hline 4. $\mathrm{OES}+$ B. decumbens & $3(11.5)$ & $22.5 \mathrm{a}$ & $23.0 \mathrm{a}$ & $23.8 \mathrm{a}$ \\
\hline 5. $\mathrm{OES}+$ B. decumbens & $4(15.4)$ & $22.5 \mathrm{a}$ & $22.3 \mathrm{a}$ & $24.3 \mathrm{a}$ \\
\hline F Treatment & & $2.23^{\mathrm{ns}}$ & $2.35^{\mathrm{ns}}$ & 1.48 ns \\
\hline CV (\%) & & 9.0 & 10.5 & 12.2 \\
\hline \multirow[t]{3}{*}{ LSD } & & 4.67 & 5.65 & 6.76 \\
\hline & & \multicolumn{2}{|c|}{$\begin{array}{l}\text { Sugarcane } \\
\text { dry matter }\end{array}$} & $\begin{array}{l}\text { Weed } \\
\text { ry matter }\end{array}$ \\
\hline & & \multicolumn{3}{|c|}{$(g)$} \\
\hline 1. One-eye set (OES) & - & 53.3 & & - \\
\hline 2. $\mathrm{OES}+$ B. decumbens & $1(3.8)$ & 30.4 & & $14.3 \mathrm{a}$ \\
\hline 3. $\mathrm{OES}+$ B. decumbens & $2(7.7)$ & 23.9 & & $17.4 \mathrm{a}$ \\
\hline 4. $\mathrm{OES}+$ B. decumbens & $3(11.5)$ & 22.8 & & $20.5 \mathrm{a}$ \\
\hline 5. $\mathrm{OES}+$ B. decumbens & $4(15.4)$ & 19.9 & & $28.3 \mathrm{a}$ \\
\hline F Treatment & & 15.32 & & $2.07^{\mathrm{ns}}$ \\
\hline CV (\%) & & 23.0 & & 41.4 \\
\hline LSD & & 15.1 & & 17.49 \\
\hline
\end{tabular}

Means followed by the same letter do not differ statistically by Tukey test $(p \geq 0.05)$ * Significant at 0.05 probability level; ** Significant at 0.01 probability level; ns Not significant. DAE - Days after emergence. ${ }^{1}$ Number of weed plants per pot

control had approximately 6.5 tillers more than the treatments in which sugarcane plants competed with 1 and 4 plants pot $^{-1}$ of $B$. decumbens.

In the last evaluation (90 DAE), the treatment in which sugarcane plants competed with 4 plants pot $^{-1}$ of $B$. decumbens showed values lower than those in the control. The coexistence of sugarcane and $B$. decumbens at this density led to a $40 \%$ reduction in the number of tillers.

According to Galon et al. (2011), reduction in the number of sugarcane tillers due to weed density is a varietal characteristic, i.e., there are cultivars which have no reduction in the number of stalks at different densities of B. decumbens. The loss in sugarcane yield, coexisting with densities of Brachiaria decumbens and Brachiaria brizantha equivalent to 15 plants $\mathrm{m}^{-2}$, may reach $60 \%$ (Tironi et al., 2013) and $50 \%$ (Galon et al., 2012), respectively. On the other hand, in competition with velvet bean, the loss of yield is close to $50 \%$ (Bressanin et al., 2016).

There were no differences between treatments for sugarcane height (Table 2), i.e., until 90 DAE, B. decumbens did not affect this characteristic of the one-eye sets.

Sugarcane dry matter was negatively affected from the density of 1 plant pot $^{-1}$ of $B$. decumbens, with mean reduction of $43 \%$ in comparison to the control (Table 2). In the treatment with higher density of $B$. decumbens, such reduction was even more drastic, reaching $63 \%$ at the density of 4 plants pot $^{-1}$. Kuva et al. (2001) found that the accumulation of $3.70 \mathrm{~g} \mathrm{~m}^{-2}$ of $B$. decumbens dry matter caused reduction of $1 \mathrm{t} \mathrm{ha}^{-1}$ in sugarcane yield. According to Paciullo et al. (2008), B. decumbens has great phenotypical plasticity, presenting itself as very aggressive to the agroecosystems because its dry matter production does not decrease when it is subjected to shading. In agreement with that, Barbosa et al. (2013) evaluated weed infestation dynamics in sugarcane and observed that, at 150 days after planting, with the crop completely shading the interrows, $B$. decumbens was the second species with highest importance value index (IVI) and covering value index (IVC). Dry matter accumulation by the weed, despite the numerical difference, was not influenced by the coexistence with the crop.

According to Figure 1A, the reduction in sugarcane shoot dry matter is related to the increase of density and dry matter of $B$. decumbens plants coexisting with the crop.

Sugarcane dry matter accumulation was negatively correlated with $B$. decumbens dry matter accumulation (Figure 1B). Maximum dry matter accumulation in sugarcane occurred in the absence of $B$. decumbens. The reduction in sugarcane dry matter was more accentuated at the point of maximum dry matter accumulation of the weed. With $30 \mathrm{~g}$ of $B$. decumbens dry matter, the sugarcane had dry matter of approximately $20 \mathrm{~g}$ (Figure 1B). On average, for each gram of dry matter accumulated by the weed, the sugarcane crop had a reduction of more than $1.2 \mathrm{~g}$ of dry matter.

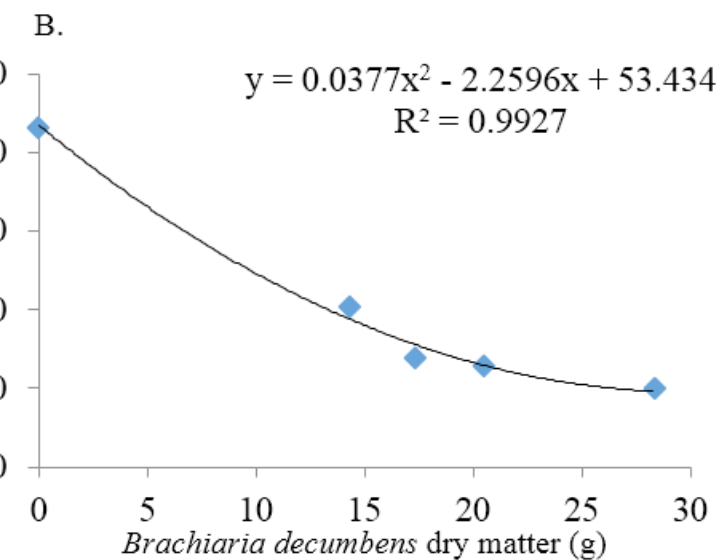

Figure 1. Sugarcane dry matter as a function of the coexistence with Brachiaria decumbens densities (A) and sugarcane dry matter accumulation correlated with Brachiaria decumbens dry matter accumulation at 90 days after emergence (B) 
Table 3. Number of tillers, stalk height, sugarcane dry matter and Panicum maximum dry matter obtained at different densities in different periods of evaluation for sugarcane

\begin{tabular}{|c|c|c|c|c|}
\hline \multirow{2}{*}{ Treatments } & \multirow{2}{*}{$\begin{array}{c}\text { Density }^{1} \\
\left(\text { plants } \mathrm{m}^{-2} \text { ) }\right.\end{array}$} & \multicolumn{3}{|c|}{ Number of tillers } \\
\hline & & 30 DAE & 60 DAE & $90 \mathrm{DAE}$ \\
\hline 1. One-eye set (OES) & - & $9.3 \mathrm{a}$ & $14.0 \mathrm{a}$ & $12.8 \mathrm{a}$ \\
\hline 2. $\mathrm{OES}+P$. maximum & $1(3.8)$ & $7.0 \mathrm{a}$ & $9.8 \mathrm{ab}$ & $9.3 a b$ \\
\hline 3. $\mathrm{OES}+P$. maximum & $2(7.7)$ & $7.5 \mathrm{a}$ & $9.5 a b$ & $8.3 b$ \\
\hline 4. $\mathrm{OES}+P$. maximum & $3(11.5)$ & $4.8 \mathrm{a}$ & $7.5 a b$ & $7.3 \mathrm{~b}$ \\
\hline 5. $\mathrm{OES}+P$. maximum & $4(15.4)$ & $5.5 \mathrm{a}$ & $6.8 \mathrm{~b}$ & $6.5 b$ \\
\hline F Treatment & & $2.59^{\mathrm{ns}}$ & $1.59 \mathrm{~ns}$ & $3.53^{\star}$ \\
\hline CV (\%) & & 24.6 & 41.2 & 31.6 \\
\hline \multirow[t]{2}{*}{ LSD } & & 4 & 6.11 & 6.56 \\
\hline & & \multicolumn{3}{|c|}{ Stalk height (cm) } \\
\hline 1. One-eye set (OES) & - & $26.3 \mathrm{a}$ & $27.3 \mathrm{a}$ & $28.5 \mathrm{a}$ \\
\hline 2. $\mathrm{OES}+P$. maximum & $1(3.8)$ & $24.8 \mathrm{ab}$ & $26.0 \mathrm{a}$ & $27.3 \mathrm{a}$ \\
\hline 3. $\mathrm{OES}+P$. maximum & $2(7.7)$ & $26.0 \mathrm{ab}$ & $27.5 \mathrm{a}$ & $28.8 \mathrm{a}$ \\
\hline 4. $\mathrm{OES}+P$. maximum & $3(11.5)$ & $22.8 \mathrm{ab}$ & $24.0 \mathrm{a}$ & $24.8 \mathrm{a}$ \\
\hline 5. $\mathrm{OES}+P$. maximum & $4(15.4)$ & $21.0 \mathrm{~b}$ & $21.8 \mathrm{a}$ & $23.5 \mathrm{a}$ \\
\hline F Treatment & & $2.23^{\mathrm{ns}}$ & $3.19 *$ & $2.54^{\mathrm{ns}}$ \\
\hline CV (\%) & & 9.0 & 10.38 & 12.01 \\
\hline \multirow[t]{3}{*}{ LSD } & & 4.67 & 5.15 & 6.64 \\
\hline & & \multicolumn{2}{|c|}{$\begin{array}{l}\text { Sugarcane } \\
\text { dry matter }\end{array}$} & $\begin{array}{l}\text { Weed } \\
\text { ry matter }\end{array}$ \\
\hline & & \multicolumn{3}{|c|}{ (g) } \\
\hline 1. One-eye set (OES) & - & 53.3 & & - \\
\hline 2. $\mathrm{OES}+P$. maximum & $1(3.8)$ & 32.9 & & $4.5 \mathrm{a}$ \\
\hline 3. $\mathrm{OES}+$ P. maximum & $2(7.7)$ & 28.1 & & $10.7 \mathrm{a}$ \\
\hline 4. $\mathrm{OES}+P$. maximum & $3(11.5)$ & 22.3 & & $8.0 \mathrm{a}$ \\
\hline 5. $\mathrm{OES}+P$ maximum & $4(15.4)$ & 15.7 & & $10.8 \mathrm{a}$ \\
\hline F Treatment & & 15.32 & & $18.87^{\star \star *}$ \\
\hline CV (\%) & & 23.0 & & 28.4 \\
\hline LSD & & 15.1 & & 18.92 \\
\hline
\end{tabular}

Means followed by the same letter do not differ statistically by Tukey test $(\mathrm{p} \geq 0.05)$ * Significant at 0.05 probability level; ** Significant at 0.01 probability level; ns Not significant. DAE - Days after emergence. ${ }^{1}$ Number of weed plants per pot

As to the number of tillers of sugarcane coexisting with $P$. maximum (Table 3), at 30 days of coexistence with the crop, there were no effects of treatments. Subsequently, at $60 \mathrm{DAE}$, significant effect was only found for the density of 4 plants pot $^{-1}$ of $P$. maximum, which decreased by approximately 7 tillers in comparison to the control (51\%). However, at 90 DAE, there was effect of density from 2 plants pot $^{-1}$ of $P$. maximum, without difference between densities, causing mean reduction of $42 \%$ between the treatment without coexistence and the mean of the treatments with the 3 highest densities.

For sugarcane height (Table 3 ), as occurred with the coexistence with $B$. decumbens, significant difference was only found at density of 4 plants pot ${ }^{-1}$ at $30 \mathrm{DAE}$. From this point on, there was no difference, i.e., until 90 DAE the $P$. maximum also did not affect this parameter of sugarcane plants.

Considered as perennial weed, $P$. maximum is a robust plant, strongly cespitose, rhizomatous, erect, 1 to $2 \mathrm{~m}$ high, forming large clumps. Its stalk has dense hairs in the nodes. Its leaves are glabrous, 20 to $70 \mathrm{~cm}$ long, and its reproduction can be through seeds and rhizomes. It is a tall, highly vigorous weed, which significantly interferes with agricultural crops (Lorenzi, 2014).

The dry matter accumulated by sugarcane was negatively affected by all densities of $P$. maximum, and 1 plant pot $^{-1}$ of this weed species reduced sugarcane dry matter by $38 \%$, more aggressive than $B$. decumbens. Pellegrini (2000) observed that one plant of $P$. maximum was able to accumulate large amount of nutrients after 90 days growing under nutrient solution, which led to expressive gains in competitiveness compared with other species studied. When there is competition between similar species, i.e., sugarcane and $P$. maximum, it is understood that the interference between these plants is more aggressive because their needs for resources are very alike (Lamego, 2010).

Eucalyptus seedlings coexisting with $P$. maximum at densities equal to or higher than 4 plants $\mathrm{m}^{-2}$ had reductions of 30 and $46 \%$ in stalk diameter, 25 and $22 \%$ in plant height, 40 and $31 \%$ in stalk dry matter, and 61 and $54 \%$ in branch dry matter at 110 and 190 days after transplanting, respectively (Dinardo et al., 2003), thus demonstrating the aggressiveness of this weed species.

The dry matter accumulation by the weed, despite the numerical difference, was not influenced by the density in coexistence with the crop. Based on previous results, this species had lower dry matter accumulation than another grass crop considered as aggressive, $B$. decumbens. However, such lower accumulation was sufficient to reduce sugarcane dry matter under interference of the weed, similarly to or even more aggressive than $B$. decumbens under the same conditions of coexistence.

In a study on interference periods with mixed infestation of P. maximum and other species, Meirelles et al. (2009) found that $P$. maximum accumulated more biomass after 157 days of coexistence with the crop, in comparison to the other weeds studied. According to Kuva et al. (2003), dry matter accumulation of $1.27 \mathrm{~g} \mathrm{~m}^{-2}$ in $P$. maximum led to reduction of about $1 \mathrm{tha}^{-1}$ in sugarcane yield. Studying the interference of different weed species in the initial development of sugarcane grown from one-eye sets, Zera et al. (2016) concluded that the species $P$. maximum was the most aggressive to the crop, reducing height, tillering and dry matter accumulation by the cultivar IAC95-5000. The loss in sugarcane yield due to the interference caused by Panicum sp. may reach 62\% (Odero et al., 2016).

There was a negative linear response of sugarcane dry matter accumulation to the infestation densities of $P$. maximum (Figure 2A); for maximum estimated dry matter accumulation of $47.6 \mathrm{~g}$, each $P$. maximum plant added caused reduction of $8.6 \mathrm{~g}$. According to the regression equation (Figure 2B), sugarcane dry matter accumulation decreased by $31.39 \mathrm{~g}$ with a dry matter accumulation of $10 \mathrm{~g}$ in the P. maximum. In other words, every $1.0 \mathrm{~g}$ of dry matter accumulated by the weed caused a mean reduction of $3.14 \mathrm{~g}$ in the dry matter of the crop.

Based on the correlation between dry matter accumulation in sugarcane and P. maximum (Figure 2B), it can be observed that this species caused more expressive negative effects on the sugarcane development than $B$. decumbens.

There was no difference between weed species with respect to sugarcane growth (Table 1). However, the dry matter accumulation of $P$. maximum at the end of the evaluation was lower than that of $B$. decumbens $(\mathrm{p}<0.05)$, i.e., for the same effect on the initial growth of sugarcane, the $P$. maximum accumulated less dry matter, indicating higher aggressiveness compared with $B$. decumbens. 

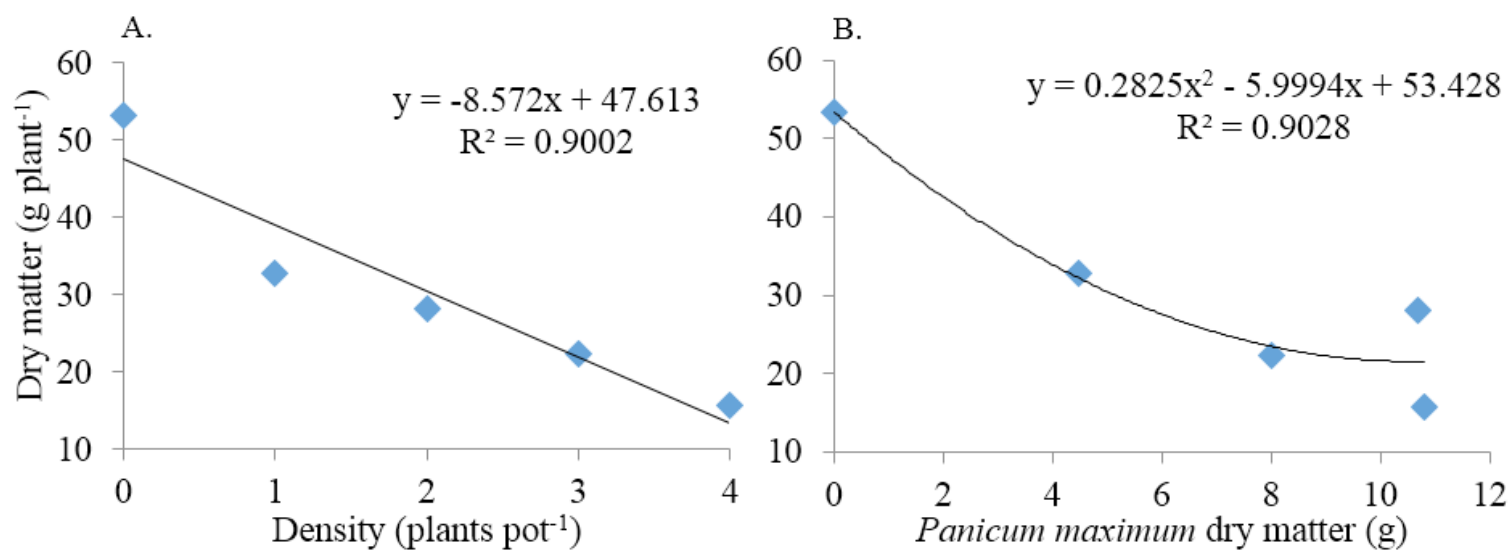

Figure 2. Sugarcane dry matter as a function of the coexistence with Panicum maximum densities (A) and sugarcane dry matter accumulation correlated with Panicum maximum dry matter accumulation at 90 days after emergence (B)

\section{Conchusions}

1. Brachiaria decumbens and Panicum maximum caused reductions in the initial growth of sugarcane plants, grown from one-eye sets, proportional to the increase in weed density.

2. Panicum maximum is more aggressive than Brachiaria decumbens to the initial development of sugarcane plants grown from one-eye sets.

\section{Literature Cited}

Alvares, C. A.; Stape, J. L.; Sentelhas, P. C.; Gonçalves, J. L. M.; Sparovek, G. Koppen's climate classification map for Brazil. Meteorologische Zeitschrift, v.22, p.711-728, 2013.

Barbosa, E. A.; Santos, L. D. T.; Santos Júnior, A.; Costa, G. A.; Cruz, L. R.; Barros, R. E.; Santos, I. T. Infestation dynamics of weed in sugarcane varieties. Bioscience Journal, v.29, p.1920-1931, 2013.

Barros, F. F.; Milan, M. Qualidade operacional do plantio de canade-açúcar. Bragantia, v.69, p.221-229, 2010.

Beauclair, E. G. F.; Scarpari, M. S. Noções fitotécnicas. In: Ripoli, T. C. C.; Ripoli, M. L. C.; Casagrandi, D. V.; Ide, B. Y. (org.). Plantio de cana-de-açúcar: Estado da arte. Piracicaba: Livroceres, 2006. Cáp.4, p 80-91.

Bressanin, F. N.; Jayme Neto, N.; Nepomuceno, M. P.; Alves, P. L. C. A. Períodos de interferência de mucuna-preta na cultura da canade-açúcar. Ciência Rural, v.46, p.1329-1336, 2016. http://dx.doi. org/10.1590/0103-8478cr20150630

Dinardo, W.; Toledo, R. E. B.; Alves, P. L. C. A.; Pitelli, R. A. Efeito da densidade de plantas de Panicum maximum Jacq. sobre o crescimento inicial de Eucalyptus grandis W. Hill ex Maiden. Scientia Forestalis, v.64, p.59-68, 2003.

Fontes, J. G. de G.; Fagundes, J. L.; Backes, A. A.; Barbosa, L. T.; Cerqueira, E. S. A.; Silva, L. M. da; Morais, J. A. da S.; Vieira, J. S. Acúmulo de massa seca em cultivares de Brachiaria brizantha submetida a intensidades de desfolhação. Semina: Ciências Agrárias, v.35, p.1425-1438, 2014.

Galon, L.; Tironi, S. P.; Faria, A. T.; Silva, A. F. da; Silva, A. A. da; Concenço, G.; Borges, E. T.; Rocha, P. R. R.; Ferreira, E. A.; Aspiazú, I. Interferência da Brachiaria brizantha nas características morfológicas da cana-de-açúcar. Planta Daninha, v.29, p.1029-1036, 2011.

Galon, L.; Tironi, S. P.; Silva, A. F. da; Beutler, A. N.; Rocha, P. R. R.; Ferreira, E. A.; Silva, A. A. da. Disponibilidade de macronutrientes em cultivares de cana-de-açúcar submetidas à competição com Brachiaria brizantha. Ciência Rural, v.42, p.1372-1379, 2012.
Kuva, M. A.; Gravena, R.; Pitelli, R. A.; Christoffoleti, P. J.; Alves, P. L. C. A. Períodos de interferência das plantas daninhas na cultura da cana-de-açúcar. II - Capim brachiaria (Brachiaria decumbens). Planta Daninha, v.19, p.323-330, 2001.

Kuva, M. A.; Gravena, R.; Pitelli, R. A.; Christoffoleti, P. J.; Alves, P. L. C. A. Períodos de interferência das plantas daninhas na cultura da cana de açúcar. III - Capim-Braquiária (Brachiaria decumbens) e Capim-Colonião (Panicum maximum). Planta Daninha, v.21, p.37-44, 2003.

Lamego, F. P. Impacto da morfologia vegetal na competição entre plantas. In: Ribas, V. (ed.). Interação negativa entre plantas. Porto Alegre: Evangraf, 2010. Cáp.7, p.111-128.

Lorenzi, H. Plantas daninhas do Brasil: Terrestres, aquáticas, parasitas e tóxicas. 4.ed. Nova Odessa: Instituto Plantarum, 2008. 640p.

Lorenzi, H. Manual de identificação e controle de plantas daninhas. 7.ed. Nova Odessa: Instituto Plantarum, 2014. 384p.

Meirelles, G. L. S.; Alves, P. L. C. A.; Nepomuceno, M. P. Determinação dos períodos de convivência da cana-soca com plantas daninhas. Planta Daninha, v.27, p.67-73, 2009.

Odero, D. C.; Duchrow, M.; Havranek, N. A Critical timing of Fall Panicum (Panicum dichotomiflorum) removal in sugarcane. Weed Technology, v.30, p.13-20, 2016. https://doi.org/10.1614/ WT-D-15-00091.1

Paciullo, D. S.; Campos, N. R.; Gomide, C. A. M.; Castro, C. R. T. de; Tavela, R. C.; Rossiello, R. O. P. Crescimento de capim-braquiária influenciado pelo grau de sombreamento e pela estação do ano. Pesquisa Agropecuária Brasileira, v.43, p.917-923, 2008. https:// doi.org/10.1590/S0100-204X2008000700017

Pellegrini, M. T. Interferência inter e intra-específica de Brachiaaria decumbens, Panicum maximum e Eucaliptus grandis por macronutrientes. Jaboticabal: Universidade Estadual Paulista, 2000.76p.

Raij, B. van; Andrade, J. C. de; Cantarella, H.; Quaggio, J. A. Análise química para avaliação da fertilidade de solos tropicais. 1.ed. Campinas: Instituto Agronômico de Campinas, 2001. 285p.

Santos, F. C.; Tachio, V. H.; Freitas, A. S.; Castro, E. M.; Davide, L. C.; Souza Sobrinho, F. Adaptive leaf anatomical characteristics of Brachiaria ruziziensis (Poaceae) genotypes in different environments. Acta Scientiarum. Biological Scienses, v.35, p.579584, 2013.

Silva Júnior, C. A. da; Carvalho, L. A. de; Meurer, I.; Libardi, P. L.; Silva, M. A. C. da; Oliveira, E. C. A. Alterações nos atributos físicos de um Latossolo Vermelho sob diferentes métodos de preparo para o plantio da cana-de-açúcar. Revista Agrarian, v.3, p.111-118, 2010. 
Tironi, S. P.; Teixeira Filho, C. M.; Faria, A. T.; Galon, L.; Silva, A. A.; Barbosa, M. H. P. Interferência de populações de Brachiaria brizantha na produtividade de cultivares de cana-de-açúcar. Revista Brasileira de Ciências Agrárias, v.8, p.21-26, 2013. https:// doi.org/10.5039/agraria.v8ila1812
Victoria Filho, R.; Christoffoleti, P. J. Manejo de plantas daninhas e produtividade da cana. Revista Visão Agrícola, v.1, p.32-37, 2004.

Zera, F. S.; Schiavetto, A. R.; Azania, C. A. M. Interferência de plantas daninhas em mudas pré-brotadas (MPB) de cana-de-açúcar nas tecnologias Plene PB, Plene Evolve e MPB-IAC. Revista STAB, v.34, p.15-19, 2016. 